\title{
An Adures
}

ON

\section{INHERITED SYPHILIS.}

Drhivered in Opening a Discussion before the SOOIRTY FOR THE STUDY OF Disense in Chimdran.

BY R. CLEMENT LUCAS, B.S., M.B.Lond., F.R.C.S., CONSULTING SURGEON TO GUY'S HOSPITAL AND TO TEE EVRLINA HOSPITAL DOR CHILDREN.

$\mathrm{OF}$ : the three terms applied to this form of the disease(1) Congenital, (2) Hereditary, (3) Inherited-I greatly prefer the third. Congenital, besides belng objectionable in form and suggestion, is not universally true; Hereditary suggests something that may be passed on indefinitely, of which there is no proof; whilst Inherited implies only something derived from the parents which is detachable like lortune or misfortune, and this more correctly expresses the passing on of the splrochaetes to the ofispring.

\section{The Micro-organism.}

The cause of syphills, whether inherited or acquired, is the presence in the blood and tissues of the same organism whioh can be demonstrated in the various secondary lestons, in the blood, and in the internal organs.

The Epirochata pallida is a protozoon of eplral form from if to $20 \mu$ in length (about half to three times the diameter of $a$ ' blood corpuscle) and $\frac{1}{4} \mu$ in dlameter, with a flagellum at either extremity. It is: very motile, and its motility is of three kinds-a lashing, corkscrew, and \& to-and-fro movement. It stains pale pink with Glemsa's fluid; whilst the coarser, highly-refracting Spirachaetc refringens, with which it is often associated, stains dark purple.

The Mode of Transmisgron.

The discovery of the canse of the disease necessitates the rearrangement of our former views as to its transmission. Those who remember the revolution in though casaed by the discovery of the tubercle baclllus-how that the long-taught diathesls gradually receded into the background and the danger of contagion by inter-communication in houses and familles grew into importance-wIll be prepared for some change of idea in reference to syphills.

To my mind inheritance from the father alone is now sputientirely out of court, and it follows that infection of a mother by her syphillitic fetus can never occur. For how is it possible that a splrochaete which is highly motlle and whose length averages rather more than the diameter of a blood corpuscle can penetrate an ovum $-\frac{1}{2}$ th of an inch in diameter and multiply without destroylng it. I lay th down as an axiom, to be demolished if you will by discusslon, that inheritance is invariably through the syphilized mother. This is supported by Colles's law that a syphilitic infant cannot cause a chancre on the nlpple of its mother when suckling.

It would seem that when virulent the splrochaetes penetwate the chorion or placenta and occasion miscarriages, macerated fetuses, or premature births; but when the virus is attenusted by time or treatment the placenta forms a complete protection to the developing fetus, and it is the separation of the placenta at birth which allows the Infection to take place through the umbilical veln. Hence the regularity of the secondary exanthemstous stage from a fortnight to three months after birth. In these oases the separation of the placenta is the first stage and corresponds to the chancre of acquired syphilis.

Colnes's Law.

I alluded to Colles's law (which was first stated in 1837) in support of the argument that the woman was always first syphillzed before the embryo or infant. The law is that a woman glving birth to a syphilltic infant cannot be inoculated with syphilis by the infant when she is suckling It; In other words, though the mother may have shown no definite signs of syphills, she is immune; whereas the syphilitic infant put to the breast of a healthy woman may Inoculate her nipple and convey syphills to her.

Hitherto Colles's law has been used as an argument in support of the view that the mother may get a mild form of agphills from her ayphilitic fetus, whose syphilis is supposed to be derived entirely from the father. But the law of immunity will remain equally true if it be supposed that the mother is first Inoculated by the father, a large dose of the protozoon causing an obvious eruptive syphilis, and a small dose a syphilis which misses the eruptive stage.

8yphills in a man is generally admitted to be capable of transmission to a succeeding generation for a much shorter time than ayphilis in a woman, and this supports the vlew I have stated, namely, that for transmlssion, it is necessary that the wnman be first infected.

Transmission BT MnK.

The question whether the milk of a syphilitic female may infect a healthy infant at the breast has been discnssed for two and a half centurles since Ambroise Paré, in the seventeenth century, quaintly observed:

Infants suckled by syphilitic nurses are infeoted by them, seeing that the milk is nothing bat whitened blood, which, being infected by the virus, the child fed with it imbibes the same qualities.

Hunter, founding his argument on ineffectual attempts to inoculate the blood of a eyphilitic person, came to the conclngion that not 'only the blood, but every secretion derived from it, such as milk, saliva, persplration, etc., could not convey the disease. But his experiments were inconclusive and hls deductions incorr ect. Pellizzari succeeded In inoculating the blood of a syphilitic person, and, if Voss's experiment is to be trusted, milk has been directly inoculated also.

I showed a remarkable case bearing on this sabject before the Royal Medical and Chirurgical Society in 1881. A woman, aged 30 , gave birth to a healthy chlld on December 11th, which she suckled. ... The following Easter her husband Inoculated her with syphilis, but she continued to sackle the child. She consulted me three months later when suffering from severe secondaries, squamous eruption, sore throat, condyloms and loss of hair, but the child showed no sign of infection. The mother was then treated with small doses of mercury. She and the child were shown when the latter was 10 months old. He had continued to suckle, and remained plump and in perfect health, though the mother still had patches of circinated squamous syphillde on her arms. During the two years the mother remained under my care for treatment the child showed no signs of inherited syphills.

The importance of this case rests on the fact that the mother had suckled her chlld for three months after her infection before any treatment was commenced, so that it cannot be argued that the Infant was taking the antidote in the mother's milk with the polson, and so escaped a source of possible inoculation; but it proves that the milk of a eyphilitic woman, when received into the alimentary tract of an infant, need not convey any infection to the child.

Transmission by Stien.

It is obvious, as the "greater cannot be included in the less, that a spirochaete cannot be carried in a spermstozoon; but this does not exclude the possibllity of the spirochaetes being conveyed by. the fluid parts of the semen.

The early experiments of inoculation by Mireur falled, but if the recent results obtained by Finger on monkeys be correct the semen of syphllitic men is inoculable. It seems almost necessary that it should be so to account for the cases of inherited syphills conveyed after the healing of the chancre. If the presence of the spirochaetes can be with certainty demonstrated in the semen of men suffering from recent syphilis much doubt would disappear; and, in the cases where no chancre could be traced in the woman, the probability of the infection being carrled through the uterus, after the disintegration of its lining membrane at any menstrual period, would be apparent.

Transmission to thr Third Ghanation.

Another question much open to discussion is whether gyphills inherited is capable of transmission to the third generation. If the tertiary symptoms, occurring ten or twenty years alter inoculation, can be proved to be due to renewed activity of the splrochaetes in certain situations, 
there seems to be a fair possibllity of their being carried to 8 - third generation. Bat the question is beset with difficulties, since you must prove the sexual purity of two persons up to the time of maturity, and these are generally persons in whom a tendency to vice is also hereditary, for it is known that a person the subject of inherited syphilis is not immune from reinoculation after a certain period.

Hutchinson mentions 8 cases that have come under hls observation of persons who presented signs of inherited syphilis, and who married, but whose offspring showed no evidence of the disease. On the other hand, Edmond Fournler collected 116 cases, 59 of which he thought were to be relled upon as showing transmission to the third generation ; and R. W. Taplor has published others. Dr. D. M. Hutton brought a case before this Bociets, which is published in the first volume of our Reports, and is there critlicized by Dr. Ashby and others.

My own experience is limited to one case, but it is of unusual importance, as both parents showed signs of inherited syphilis which were obvious and unmistakable. $A$ blind man attended a school for the blind, where he met a blind woman for whom he developed a feeling of affectlon. They were both blind from interstitial corneoIritis, and they both presented the typical physiognomy of the inherited disease-notched teeth and scars around the mouth. They married, and at the time the man came under my care their first chlld was about 2 months old. The blind wife wasibrought up to visit her husband, and, seeing she was marked by : the same disease, I sent for the infant, which presented no evidence whatever of syphilis, nor did it develop any symptom of inherited disease during the months I was able to keep it under observation. This case, in which there should have been double inheritance, showed, so long as I was able to watch It, complete immunity.

The Infast Mortarity.

There is probably no disease responsible for such an enormous destruction of human life in its earlier stages as that caused by syphilitic parentage. But my experience shows that this mortality is greatest in those familles where both parents have suffered from chancre syphills and obvious secondaries. The severity of the infection

and ineffective treatment, or lack of treatment, are the two factors which determine the mortality. I give two illustrations.

Case I.

E. . S. had been married eleven years, and suffored three months after marriage from rash and sore throst. The first child was stillborn twolve months after marriage, and was miscarried at the sixth month. The second chlld lived (the mother being at this time under treatment), but had severe snuffles and rash, is very delicate, and has recurrent sores and eruptions. The third, lourth, fifth, sixth, seventh, elghth, and ninth children were all born at full time, but all died, from 8 few minutes to within two or three months of birth. The tenth child was brought up for trestment suffering severely from snuffes, stomatitis, and coppery shing eruption. Thus two weak children only were living out of ten.

\section{Casse Ir.}

R. C. three weeks after marrlage, suffered from sores on valva followed bj rash and sore throat, for which she had no prolonged treatment; a pale, cacheotic-looking woman. The first child, ten months after marriage, was stillborn at the seventh month. The second child was prematurely born at the eighth month, and lived a day. The third child, born at fall time. came out a fortnight later in large brown spots and had snuffles, and was teken to Gur's Hospital and treated by blu oint the inheritance. The fourth ohild did not come ont in an orap tion till 5 weeks old. He died at 6 weeks. The fifth child, 8 boy, came out in an eruption at 5 weeks, and died at 7 weeks. The sixth child was stillborn. The seventh child premsturely born at the elghth month with an ornption npon hor gurvived The eighth child, a girl, had a rash soon after birth, and died on the eighth dey. The ninth, also a girl, was born healthy, but an eruption came out at the third week. Bhe was trested, but died at 11 weoks. The tenth child, a fine boy at birth, came out in an eruption three weeks after birth, and was brought up for treatment. He was suffering from sym. metrical squamous syphilide of legs, feet, arms, and ears, little on body, ulcerstion of mouth and buttocks, and severe snuffles. Again two living out of ten.

The 8hcondant Stage.

The trite definition that syphilis is a "lever diluted by time," given by the late Dr. Moron, is applicable to the inherited as well as to the acquired disease.

I argued that the primarg stage is the separation of the placenta and the infection of the Infent through the umbllical vein. The secondary or exanthematons stage commences from the second week to as late as the thilfi month. It is characterized by eruptions, whlch may vary. from slight brown macular syphilide to pompholy $x$, by onuffles, stomatitls, condyloma, wrinkled skin and wasting, enlargement of the spleen and liver. Then follow certain changes in the bones; In severe cases perhaps eplphysitls;; glving rise to pseudo-paralysis, Parrot's nodes, causing' natiform skull and square forehead, craniotabes, and bent bones.

It cannot be too strongly in. sisted on that the molst eruptions and alcerations about the month and anus, as well as the vesicular skin affeotions, are charged with the spirochaetes. and highly contagious.

From the second to the sixth year there is commonly a rest in the symptoms that are regarded as characteristic, but the tibiae may become thickened. from perlostitis, or a joint may become swollen and painful, and resolve under mercurial treatment.

But now the characteristls physiognomy has been gra dually formed-the flattened nose, the square forehead, the radiating lines from the mouth, the stunted figure andi pallid face; and then, durIng the second dentition, we look for the three signs pointed out by our great observer, Jonathan Hutchlnson - the notched inclsor teeth, intergtitial corneltis, and gyphilitic deafness. Associated with such signs, or occasionally independent of them, gummatous destruction of the soft or hard palate may occur, and ulcerations of the $\mathrm{skjn}$ and cellular tissue. Destruction of the nasal bones, caries of the forehead and skull, of the long bones, and dactglitis may take place as the result of the inherited disease.

The teeth Mr. J. Hutchinson described as so characterIstic of the disease are the notched and narrowed incisors especlally the central incisors of the upper jaw. This defect is brought about.by arrest in development of the central columella of which each incisor has three. But I wish to draw special attention to the characteristic change brought about by the disease in the first molars described by the late Mr. Henry Moon many years age, since this change has recently been rediscovered both in America and on the Continent. The diagram which I show is taken from the fourth edition of Bryant's Surgery, published in 1884, wherein the article on teeth is written by Mr. Moon. He figures and describes the syphilitic first molar as "reduced in size and dome shaped through the dwarfing of the central tubercle of each cusp." He also contrasts these teeth with mercurial teeth and syphilitic-mercurial teeth. The change in the molar is of some clinical importance, since occasionally it is characteristic when the incisors are normal. 
Ergs AND EARs.

The eges may become affected at an early stage by a choroido-retinltis, which may leave permanent changes essily recognized by ophthalmoscopic examination; and irltis, though rare, may occur during the eruptive stage. Interstitial keratitis is most frequent between the ages of 6 and 16, but may occur much later, and rarely earlier. It Is highly characteristic of the inherited disease.

Like the eyes, the ears are attacked by different affections in the early and late stages. During the eruptive stage, otitis media may commence as an extension from the inflammation of the naso-pharynx, whilst during the second dentition a progressive deafness of labyrinthine origin may cause complete loss of hearing.

INHERITED SYPHILIS ATTACKING THE VISORRA

Much work has been done in demonstrating the disease In the varlous viscera, not one of which appears to be exempt, and there is probably a large field still open here for further investigation. Enlarged spleen and liver assoclated with rickets may be proved almost invariably to be of ayphilitic origin.

The disease attacks the various organs in two forms : as a small cell infiltration nsually following the course of the vessels, which in 1 ts development and decline may lead to fibrosis and consequent atrophy; and as a gummatous tumour, which is less common.

When the inherited disease attacks both testicles or both ovarles at an early age, and brings about their fibrosls and atrophy, a condition known as "Infantllism" Is produced at a period when the sexual characteristics chould be pronounced.

\section{The Nervots Sxsi EM.}

Mach difference of oplnion exists as to the frequency of nervous dlsease dependent on inherited syphills. Whilst some are inclined to attribute every conceivable weakness, paralysis, or mental defect to this disease, others regard the nervous lesions dependent on it as infrequent. A certain proportion of eplleptics, deatmutes, and idiots, but not a large percentage, show signs of inherited syphilis. On the other hand, syphilitic endarteritis of cerebral vessels, gummsta on nerves, and sclerosis of brain and apinal cord have been observed by competent observers. One of the most interesting observations of late jears is that some cases of hydrocephalns are dependent on inherited ayphills, and are curable by mercary.

The Need of Criticism in Diagnosis.

In conclusion, I wish to insist on the importance of weighing carefully all the evidence before determining that a particular affection is due to Inherlted syphilis. Every deformity, from dislocated hip to cleft palate, all defects such as hernia, Infantile paralysis of varlous kinds, and even naevl, have been described by-various writers as dependent on inherited syphillis, and as if better to cover the anomalles the .term "para-syphilis" has been invented to add to the confusion.

I need scarcely waste time in combating such crude generalizations as that "all rickets takes origin in sypbilis," when any puppy taken from a litter and deprived of proper tood and exerclse will certainly develop this disease.

Equally crude statements have been made as to other diseases. We do not deng that persons whose constitutions have been weakened by disease are llable to pro. duce degenerates in succeeding generations; but in future the most certain test of the disease being gyphills will be the presence of the Spirochacta pallida in the part affected. Thls organism has an extraordinary persistency, producing local symptoms atter lengthened periods, but happlly we have in mercury and the iodides drugs which control its development and bring about its destruction.

The Temperance Summer School, organized by the Department of Scientific Instruction and Information (United Kingdom Band of Hope Union), will be held a Ardenconnel on the Garelooh, near Helensburg. Scotland, from June 20th to July 3rd. The objects of the School are first, to give some up-to-date and definite teaching to meet the educational needs of the day; secondly, to foster a spirit of comradeship and mutual help amongst temperance friends and workers ; and, thirdly, to secure an enjoyable holiday trip. Full particulars as to terms, etc., will be sent on application to the Director, Walter N. Edwards, 60, Old Bailey, London, E.C.

\section{THE MEDICAL INSPECTOR OF SCHOOLS \\ AS A PSYCHIATRIST.}

By T. 8. CLOUßTON, M.D., LL.D., LECTURER ON MENTAL DISEASES, EDINBURGH UNIVERSITY.

The Medical Inspector of Schools has come on us 80 suddenly at the last that it is very doubtinl whether his vast potentialily and the significance of his work are at all realised by the mass of our profession. It seems to me that next to the medical officer of health he may turn ont to be the greatest health boon which Parliament has bestowed on the people of this country. One sees that many questions will have to be solved as to the right sort of man for the place, as to how he ought to be educated, what he ought to know, to what things he ought to direct special attention, and in what special relationship he is to stand to the School Board, the Education Department, and the profession of medicine. It will be of enormous importance that a general publlc interest should be taken In him and his work. That of itself would be an education to the general public. I hope his reports will always be published in the newspapers and that they will be intelligently discussed there. Of the hundreds of medical men who will be appointed inspectors, most, we trust, will be wise men, but it is certsin that some will be foolish and many will be faddists. The principle laid down by the Board of Education under the head of "Character and Degree of Medical Inspectlon" seems sourd enough. Few medical men will object to the following paragraph :

From what has been said it will be clear that the fundamental principles of Section 13 of the new Act is the medical exsminstion and supervision not only of children known or snspeoted to be weakly or alling, bat of all chlldren in the elementary schools, with a view to adapting and modifying the system of education to the needs and capacities of the chlldren, securing the early detection of unsuspected defects, checking inclpient maladies at their onset, and furnishing the facts which will guide the education authorities in reletion to physical and mental development during school life. .. The training of the mental faculties must not be divorced from physical culture and personal hyglene. It is these primary requirements which mast first recelve attention.

To some of us who have been members of the medical profession for many years, and who bave witnessed the governmental ignorance and public indifference of 8 quarter of a century ago in regard to medical views of education, such a paragraph is both surprising and most welcome. It should be the source of the profoundest thankiulness to all doctors and to all those of the public who believe in the great mission of modern medicine. In an article in the Times of November 25th, 1907, the following paragraph, which may be taken as representing the vews of the intelligent layman, occurs:

The general principle anderlying the memorendum is that the sotusl work of school inspection mast be carried out in intimate conjunction with the existing publio health anthorltles and under the thorough supervision in each locality of the medical officer of - health, but subject to the control of th medical department of the Bosrd of Educstion, Instead of to that of the corresponding department of the Local Governmen Bosrd. The result aimed at is clearly the harmonlous co-operation of educationel with senitary anthorities, with security tlon aisher. In other words, school hyglene is to. be treated as an integral portion of the sanitary administration of the country, integral portion of the sanitary administration of the country, but still as a branch of that adminis

These references to "mental development," to the "mental faculties," and to the requirement of "special knowledge" In the school inspector brings me to the object of this paper. General cleanliness, body-nutrition, the eses, the ears, the throat, the chest, and the teeth will all have to engage the attention of the school inspector. But the dominating organ of all-the brain - meg stand some chance of belng neglected, though it is the organ which is to be chiefly educated, and which should be most of all in evidence.

Referring to public health as it has hitherto been studied, we mav look in vain in any of its tertbooks for any reference to the mental health of the community as requiring attention or preventive measures. It may well be that if the attention of the inture medical inspector of schools is not strongly directed to the braln of the child, he mas be in danger of neglecting it in his investigations 